Lektor, dr. phil.

Institut for Kulturvidenskaber, SDU

\title{
TOPOLOGISK POETIK I VIKTOR ŠKLOVSKIJS PROSATEORIEN ${ }^{1}$
}

Skønt det ikke eksplicit italesættes, spiller det litterære topos på mange måder en afgørende rolle i den russiske litteraturteoretiker Viktor Šklovskijs hovedværk Prosateorien (O teorii prozy, 1925) ${ }^{2}$. Her bruges en kritisk diskussion af det symbolistiske begreb om litteraturen som en genial tænkning i billeder og af den såkaldt etnografiske skoles litterære motivforskning nemlig som afsæt til at formulere, hvad man kan opfatte som en topologisk poetik: en poetik, der tager udgangspunkt i det 'formelagtige' som centralt litterært greb. Snarere end at udtrykke forfatterens personlige tanker og følelser refererer de litterære billeder, ifølge Šklovskij, til konventionelle

1 Artiklen tager udgangspunkt i kapitlet "Viktor Šklovskijs prosateori" i Kluge (121158), der imidlertid ikke anlægger en topologisk vinkel, men fokuserer på de romanteoretiske implikationer af Šklovskijs prosateori.

2 Selvom der findes en udmærket tysk oversættelse ved Gisela Drohla (Theorie der Prosa, 1984), har jeg baseret min oversættelse på B. Shers engelske version (Theory of Prose, 1990). Der findes nemlig ingen autoriseret dansk oversættelse af værket. Kyrilliske bogstaver translittereres forskelligt på forskellige sprog. Derfor staves Šklovskijs navn forskelligt i artiklen: når jeg refererer til den engelske oversættelse, står der Shklovsky, fordi det er sådan forfatterens navn skrives på engelsk, men ellers bruger jeg "Šklovskij", som er den danske (og tyske) translitteration. 
formler, der cirkulerer i sproget på tværs af tid og rum. Langt fra at henvise til oprindelige sæder og skikke peger de litterære motiver på litteraturens revitalisering af "automatiserede" sprogformer. Således reelt redefineret som topoi i den mest grundlæggende forstand - som almensteder eller gentagelser af etablerede former ${ }^{3}$ - bliver de litterære billeder og motiver for Šklovskij ikke kun en nøgle til forståelsen af selve det litterære eller "litterariteten" (literaturnost) ${ }^{4}$ som en genoplivende, ja, ligefrem frelsende ${ }^{5}$ "fremmedgørelse" (ostranenije) af det døde sprog (Robinson 79-164). De anskueliggør endvidere den litteraturhistoriske udvikling som en kæde af sådanne fremmedgørelser.

Med sin bestemmelse af litterære billeder og motiver som demonstrativt repetitive greb, der har til intention at fremmedgøre læseren gennem blotlæggelse af kunsten, udgør Prosateorien uden tvivl et originalt bidrag til den æstetiske topologi. I sidste instans hviler den imidlertid på en tilsyneladende utidssvarende litteraturfilosofisk præmis: forestillingen om litteraturen som et privilegeret diskursivt rum, hvor livsverdenens tabte idealitet genskabes (Eagleton 1-14). Heri adskiller Šklovskij sig grundlæggende fra den moderne topologis store faderfigur, den tyske romanist Ernst Robert Curtius, hvis filologiske og litteraturhistoriske granskning af genkommende billeder og motiver i den latinsksprogede senantikke og middelalderlige digtning i hovedværket Europäische Literatur und Latinisches Mittelalter $(1948)^{6}$ udgør det implicitte eller eksplicitte paradigme for moderne litteraters motivforskning. I det følgende vil jeg således gennem min fremstilling af, hvad jeg opfatter som Šklovskijs topologiske poetik, implicit undersøge

3 Se Ordbog over det danske sprog: "Almen-sted, et. [2, jf. 1.2] (efter ty. gemeinplatz, -ort, lat. locus communis; sj.) sætning ell. udtalelse af almindeligt dvs.: forlængst anerkendt indhold; almindelig kendt, "fortærsket" sandhed. triviale, almindelige, og derfor uvirksomme, Almeensteder. Birckner.III.114. hvad han udtaler, hæver sig ikke over de forslidte Almeensteders Klasse. Dagbl. ${ }^{19}{ }_{11}$ 1863.2.sp.5".

4 Dette er som bekendt Roman Jakobsons begreb (lanceret i "Moderne russisk poesi" ("Novijshaja russkaja poezija", 1921)), men man kan også roligt betragte "litterariteten" som et kardinalpunkt i Šklovskijs teori.

5 Jævnfør den messianske retorik i Šklovskijs essay "Ordets genopstandelse" ("Voskrešenie sloba") fra 1914.

6 Se særligt 1954 (89-116), hvor Curtius udreder en række centrale topois kultur- og litteraturhistorie, herunder skibsmetaforik eller "verden-på-hovedet". 
den moderne topologis formfilosofiske bagland. Afslutningsvist vil jeg kort diskutere Prosateoriens styrker og svagheder ud fra en sammenligning med Curtius' udgave af topologien.

\section{POETOLOGISK VIDENSKAB MED FILOSOFISK TWIST}

Prosateoriens første tre kapitler udgør en hjørnesten i den videnskabeliggørelse af litteraturforskningen, der fandt sted i første halvdel af det 20. århundrede. Kapitel 1 udgøres af det epokegørende essay "Kunsten som greb" ("Isskustvo kak prijom"), først udgivet i 1917. De tanker, der fremsættes her, kan blandt andet anskues som en væsentlig baggrund for den strukturalistiske litteraturteori og har alene heri betydelig interesse. Strukturalismens begreb om ordkunsten som et sindrigt system af indbyrdes relaterede og genkommende former er ganske vist for længst blevet afløst af mere dynamiske og omverdensorienterede modeller; men det spillede en afgørende rolle for den moderne litteraturvidenskabs etablering som en fra de forskellige nationalfilologier selvstændig akademisk disciplin.

Prosateoriens betydning for den sammenlignende litteraturvidenskab går imidlertid ud over det rent faghistoriske. Med sin understregning af litteraturens diskursive egenartethed samt af det samfundsmæssige potentiale, der gemmer sig netop i denne egenartethed, konsoliderer Šklovskij i dette værk på flere måder den moderne forestilling om litteraturen som en særlig - og særlig vigtig - måde at kommunikere på. Samtidigt støber han i forlængelse heraf fundamentet til en poetologisk videnskab, der skal identificere og definere de lovmæssigheder, der angiveligt altid og for evigt regulerer den litterære diskurs i sine myriader af fremtrædelsesformer. ${ }^{7}$ Hermed profileres litteraturen ikke blot som en særegen diskursiv form; litteraturforskerens arbejde gives samtidigt et inciterende skær af gen-

7 Det komparative, ja, ligefrem universelle perspektiv i Prosateorien understreges af referencernes nærmest overvældende diversitet: fra antikke klassikere som Euripides, Menander, Plautus og Ovid til persiske eventyr og arabiske fortællinger, Tolstoj og Gogol og russiske folkeeventyr, Shakespeare og de italienske renæssanceforfattere, tysk 1800-tals litteratur og Cervantes, m.m. 
kendelig moderne videnskabelighed, ${ }^{8}$ ja, endda af filosofisk-eksistentiel nødvendighed.

Så enkelt kan Prosateoriens videnskabelige projekt formuleres: ud med spørgsmålet om ekstralitterær referens, ind med kortlægning af infralitterære love og strukturer (Steiner 47). ${ }^{9}$ Med Šklovskijs stadig i dag noget provokerende formulering er det "formen, som skaber indholdet", og ikke omvendt. ${ }^{10}$ Den litterære form er ikke en neutral beholder, forfatteren fylder et indhold i, der så former beholderen, ligesom en pose tager form efter det kilo appelsiner, man putter i den. Nej, den litterære form præger omvendt det indhold, som forfatteren bringer til torvs (hvad enten dette nu er et subjektivt tankeindhold eller et objektivt eksisterende sagsforhold), forvandler det til litteratur, til form slet og ret. Og netop i denne forvandlende virksomhed i forhold til det virkelige finder litteraturen sin berettigelse. For gennem sin demonstrative, selvreferentielle og fremmedgørende transformation af virkeligheden til form tvinger litteraturen os til at se denne virkelighed med nye briller; til at mærke verden på ny. ${ }^{11}$

8 Ehrlich går så vidt som til at beskrive formalismen som et neo-positivistisk fænomen: "[...] the Russian Formalists were not primarily concerned with the essence or purpose og art. Avowed champs of 'neo-positivism', they sought to steer clear of "philosophical pre-conceptions" as to the nature of artistic creation; they had little use for speculations about Beauty and the Absolute. Formalist esthetics was descriptive rather than metaphysical." (171). Som det fremgår, er jeg ikke enig i den analyse, som da også er blevet diskuteret af bl.a. Striedter (x).

9 Šklovskij identificerer og beskriver i Prosateorien en række af disse fremmedgørende strukturer - herunder forskellige former for parallelismer og gentagelser, rim og rytme, brug af fremmedord eller endda af fremmede sprog - der sammenfattes under etiketten "deceleration" (zamelenje). Se Shklovsky (24 f.).

10 Se Shklovsky 1990 (24): "Dette fænomen udtrykker det almene princip: Form skaber selv sit eget indhold. Hver gang et ords tvilling er fraværende, tages pladsen derfor af et tilfældigt eller afledt ord. [...]. Disse forskellige eksempler på en hæmmet, progressiv konstruktion optræder normalt ikke samtidigt, og der er blevet fremsat separate forklaringer på hvert af disse tilfælde."

11 Her findes i øvrigt en interessant parallel til Hans Ulrich Gumbrechts moderne topografi som en kulturvidenskabelig praksis, der har til formål at tilfredsstille begæret efter 'nærvær' generelt, herunder fortidens nærvær (se især In 1926. Living on the Edge of Time). Ligesom Gumbrecht interesserer Šklovskij sig for sanseliggørelsen, om end han lokaliserer det sanseliggørende potentiale hos digteren, ikke - eller først i anden omgang - hos kulturhistorikeren eller kritikeren. Begge 
Således falmer livet til intethed, når det ikke regnes for noget. Automatiseringen æder ting, tøj, møbler, vores koner og vores angst for krig.

Hvis mange menneskers ellers komplekse liv finder sted på et fuldstændigt ubevidst plan, er det som om det liv aldrig havde været.

Og netop for at give følelsen tilbage til vore lemmer, for at lade os føle genstande, for at lade en sten føles stenet, er mennesket givet kunstens redskab. Kunstens formål er således at lede os til viden om en ting gennem synsorganet i stedet for gennem erkendelsen. Ved at "fremmedgøre" genstande og komplicere formen gør kunstens greb perceptionen lang og "møjsommelig". Den perceptuelle proces, der findes i kunsten, har sit helt eget formål og fortjener at blive fuldt udfoldet. Kunst er en måde at erfare kreativitetens proces. Selve kunstværket er temmeligt ligegyldigt. (Shklovsky 5-6. Her som i øvrigt i min oversættelse)

Som man klart og tydeligt ser her, er fremmedgørelsen og selvreferentialiteten ikke et mål i sig selv for Šklovskij. Nok er han formalist, men han er ikke æsteticist. ${ }^{12}$ Med afsæt i Tolstojs refleksioner over kunstens rolle som en modgift mod den dræbende automatisering af tilværelsen, der lurer overalt i den slappe sprogbrug, præsenterer Prosateorien tværtimod en poetologisk videnskab med et litteraturfilosofisk twist. Netop fordi litteraturens frelsende fremmedgørelse af det virkelige besidder et omfattende samfundsmæssigt potentiale, gælder det om at identificere og beskrive den i alle detaljer for dermed at gøre litteraturens samfundsmæssige betydning gældende. Dette er, hvad Šklovskijs poetologiske videnskab går ud på, og hvad Prosateorien sigter mod. Selvom det som nævnt ikke italesættes di-

teoretikere har en aktie i fænomenologien, men Šklovskijs udgave af denne tradition er idealistisk eller husserlsk, mens Gumbrechts er mere rendyrket orienteret mod den sanselige eller æstetiske erfaring, ja, på sine steder i decideret opposition til den filosofiske æstetik, der gemte sig i Šklovskijs grundlæggende opfattelse af litteraturen som en brobygning over afgrunden mellem verden og idealitet. Jameson polemiserer (71) mod Šklovskijs idé om, at "formen skaber indholdet", men hans polemik bunder i den misforståelse, at Šklovskijs formalisme er æsteticistisk. I det omfang, Šklovskijs begreb om fremmedgørelse netop har et ekstra-litterært formål - revitaliseringen af livsverdnen - kan dette imidlertid siges ikke at være tilfældet. Der er hos ham netop ikke tale om kunst for kunstens skyld eller om en nydelse af den rene form, men derimod om hvad jeg andetsteds (Kluge 121-158) har beskrevet som en avant-gardistisk orienteret reproduktionsæstetik. Det er i denne sammenhæng i øvrigt ikke uvæsentligt, at det stalinistiske regime opfattede formalisternes arbejde som så tilpas politisk, at det blev stoppet omkring 1930 (Robinson 80). 
rekte, står toposet - som indbegrebet af det formelagtige - helt centralt i denne sammenhæng.

Den polemiske baggrund for Šklovskijs topologiske poetik, der altså forener det litteraturvidenskabelige med det litteraturfilosofiske, er todelt: På den ene side er der et iltert opgør med den romantiske litteraturkritiks seneste knopskydning, den russiske symbolisme; på den anden side finder vi en kontant afregning med det 19. århundredes historistiske tradition, som senest manifesteret i den etnografiske litteraturhistoriografi. Egentlig er der tale om én og samme kritik, for i Šklovskijs optik fokuserer begge disse samtidige litteraturkritiske skoler slet og ret for lidt på selve den litterære form og for meget på uvedkommende ekstralitterære faktorer. Uanset om det er et noetisk indhold (f.eks. et abstrakt almenbegreb eller en personlig følelse), formen siges at udtrykke, eller om det er en oprindelig skik eller historisk begivenhed, er der efter hans mening tale om et instrumentelt formbegreb, hvor formen ikke betragtes i sig selv, men kun i relation til noget andet, som den udtrykker. Selvom der således, i hvad vi for nemheds skyld kan kalde symbolisme-afsnittet (kapitel 1) og etnografi-afsnittet (kapitel 2), grundlæggende er tale om den samme argumentation, anlægger de to kapitler imidlertid henholdsvis en synkron og diakron optik: Kapitel 1 lancerer, hvad man kan kalde en topologisk litteraturteori, og i kapitel 2 præsenteres vi så for en topologisk baseret teori om den litteraturhistoriske udvikling.

IŠklovskijs arbejde med at etablere denne todimensionelle topologiske poetik viser forgængernes arbejde sig heldigvis trods alt ikke at være fuldstændigt ubrugeligt. Selvom hovedrepræsentanterne for den symbolistiske litteraturkritik og den etnografiske litteraturhistoriografi, henholdsvis Alexander Potebnja (1835-1891) og Alexander Veselovskij (1830-1906), ifølge Šklovskij, tog fejl i mangt og meget, og ikke mindst i deres instrumentelle tilgang til den litterære form, har de da forstået én ting, nemlig hvor centrale billeder og motiver er for litteraturen som specifik diskursiv form og for den litteraturhistoriske udvikling. Der er dog plads til forbedring, og Šklovskijs overtagelse af det symbolistiske og etnografiske tankegods sker således med ikke uvæsentlige forbehold. ${ }^{13}$ Helt grundlæggende omdefinerer han, 
kan man sige, symbolisternes billedbegreb og etnografernes motivbegreb til rent formale eller altså ikke-referentielle størrelser, der har deres liv i sproget alene.

\section{BILLEDE SOM TOPOS}

Første skridt i Šklovskijs kritiske revision af state of the art inden for den poetologiske tænkning er et opgør med de russiske symbolisters romantisk oprundne geniæstetik og hermed forbundne erkendelsesorienterede litteraturteori, som Prosateorien indledningsvist sporer tilbage til den indflydelsesrige lingvist og filosof Alexander Potebnjas definition af poesien som et mere eller mindre mystisk billedsprog:

På baggrund af Potebnjas konklusion, der hævder at poesi er lig med billedsprog, er der opstået en hel teori, som i forlængelse heraf erklærer, at billedsprog er lig med symbolisme. Dette forudsætter, at et billede er i stand til at tjene som gennemgående prædikat for en række udskiftelige subjekter. (Shklovsky 3)

Der er, ifølge Šklovskij, flere problemer med dette bredt antagne synspunkt. På den ene side er det baseret på en organismeæstetisk opfattelse af form og indhold som en uopbrydelig syntese, hvor formen atter en gang indtager rollen som ancilla materiae; på den anden side har forestillingen om billedets kvasi-magiske uudtømmelighed en bismag af religiøs tågesnak, der ikke går godt i spænd med Prosateoriens rationalistiske eller i al fald videnskabelige afsæt (Thompson 11-19). Potebnjas understregning af billedets vigtighed for litteraturen som diskursiv form vil Šklovskij sådant set gerne bygge videre på, men der er brug for en gentænkning af billedbegrebet. Den centrale indvending $i$ hans revision af Potebnjas symbolistiske litteraturteori er, at de litterære billeder aldrig er forfatterens originale opfindelser, men derimod genbrug af allerede eksisterende billeder:

Således tror mange stadig, at tænkning i billeder [...] er poesiens fremmeste karakteristikon. Disse mennesker må så have gået og forventet, at denne "imagistiske" kunsts historie, for nu at bruge deres egne ord, bestod i billedhistoriske forandringer. Nu viser det sig imidlertid, at billeder består og varer ved. Fra århundrede til århundrede, fra land til land, fra digter til digter, marcherer disse billeder videre uden at forandre sig. De tilhører "ingen", bortset fra måske "Gud". Jo mere man 
prøver at forklare en epoke, desto mere overbevises man om, at de billeder, man troede var skabt af en given digter, i realiteten var blevet ham overleveret i stort set uændret form. De på hinanden følgende digteriske skolers arbejde har dybest set bestået $\mathrm{i}$ at akkumulere og bekendtgøre nye former for verbalt arrangement og organisering. Disse digteriske skoler er først og fremmest langt mere optaget af disponeringen af billedsproget end af at skabe dette billedsprog. I digtningen, hvor billedsprog er noget givet, "tænker" kunstneren ikke så meget i billeder som han "ihukommer" dem. (Shklovsky, 2)

Det senromantiske symbolbegreb forvandler sig i Šklovskijs hænder til uigenkendelighed, eller rettere: til et topos. Hans påpegning af billedernes stadige reproduktion op gennem litteraturhistorien er et decideret frontalangreb på Potebnjas idé om det litterære billede som en genialt udtænkt form, hvorigennem et komplekst og variabelt tankeindhold kommer til udtryk. ${ }^{14}$ Šklovskijs kritik stopper imidlertid ikke her. For et mere grundlæggende problem ved den symbolistiske idé om, at litteraturen udmærker sig ved sit billedsprog, er, at dagligsproget også benytter sig af billeder, som f.eks. når vi taler om et bordben. Vil man ind til litteraturens kerne må man derfor, ifølge Šklovskij, se nærmere på billedets særlige funktion i den litterære tekst. Denne funktion beskrives nu som den demonstrative udstilling af kunsten eller 'grebet', der ligger i den ublu repetition af på forhånd kendte billeder, det vil sige i understregningen af billedet som konvention eller formel:

I snæver forstand vil vi kalde et værk kunstnerisk, hvis det er skabt med særlige greb, hvis formål er at sørge for at disse artefakter bliver fortolket så kunstnerisk som overhovedet muligt. (Shklovsky, 2)

I modsætning til dagligsproget, hvor billederne tjener et kommunikativt formål, benytter ordkunsten sig altså af almensteder for at understrege sig

14 Šklovskij har helt indledningsvist citeret Potebnja. Se Shklovsky (1): "Eller, med Potebnjas ord: "Billedets forhold til dét, som forklares gennem det, kan tage en af to former: enten (a) tjener billedet som gennemgående prædikat for en række stadigt vekslende subjekter, eller også (b) er billedet langt simplere og klarere end dét, der skal forklares. Eftersom billedsprogets formål således er at bringe billedets betydning i tættere kontakt med vores forstand, og eftersom et billede uden dette formål ikke har nogen mening, så må billedet forudsættes at være os mere velkendt end dét, der forklares gennem det." 
selv som litteratur. Šklovskijs opgør med symbolismen er her beskrevet i sin essens. Med afsæt i Potebnjas litteraturteori formulerer Prosateorien et begreb om den litterære billeddannelse som en dynamisk bearbejdning af allerede eksisterende billeder. Som en grum kæmpe fra et russisk folkeeventyr har han fortæret billedbegrebet og kastet det op igen i en ny og hidtil uset form: som omdrejningspunkt for en radikal reproduktionsæstetik forankret i topologien.

\section{MOTIV SOM TOPOS}

I Prosateoriens kapitel 2 gælder det så den ligeså bredt accepterede opfattelse, at litteraturen afspejler virkelige hændelser og fænomener, og at litteraturhistorikerens opgave i forlængelse heraf er en slags arkæologisk rekonstruktion af fortiden. For lige så lidt som den litterære tekst peger tilbage på forfatterens uudtømmelige tankevirksomhed, peger den nemlig, efter Šklovskijs mening, på nogen form for objektive historiske sagsforhold. Andet og afgørende skridt i hans etablering af en selvstændig poetologisk videnskab er således opgøret med den såkaldt etnografiske skole, som personificeret i litteraturhistorikeren og lingvisten Alexander Veselovskij. På baggrund af et enormt empirisk materiale bestående af russiske folkeeventyr og legender havde denne store genealogiske litteraturhistoriker som den første identificeret de litterære billeder som motiver (det vil sige som formelle enheder snarere end referentielle størrelser). Han havde samtidig beskrevet deres sammenkædning som et syuzhet, plot (snarere end en mimetisk gengivelse af et faktuelt hændelsesforløb). Men selvom Veselovskij således på mange måder havde banet vejen både for den morfologiske narratologi, som i dag primært identificeres med navne som Vladimir Propp (1895-1970) og Algirdas Julien Greimas (1917-1992), og for Šklovskijs egen topologiske poetik, ${ }^{15}$ blev han i formalisternes øjne stående på halvvejen, om man så må sige. Hans videnskabshistoriske ståsted bød ham at holde fast i den ekstralingvistiske virkelighed, som eventyrene og legenderne i al deres stiliserede formalisering, ifølge hans opfattelse, i sidste ende afspejlede. Og det er hér, Šklovskij sætter sit angreb ind. For 
nok havde Veselovskij set rigtigt, da han brugte sin omfattende empiriske vidensbase til at identificere universelle love på baggrund af sine motivstudier, men han tog ikke skridtet fuldt ud:

Mange indvendinger kan rejses mod etnografens teori om motivers oprindelse. Tilhængere af denne teori har forklaret ligheden mellem narrative motiver ved eksistensen af identiske socioøkonomiske forhold og religiøse opfattelser. Denne teori beskæftiger sig udelukkende med motiver om sådan og berører kun flygtigt fortælleskemaers indbyrdes indflydelse på hinanden. Hvad angår de love, der styrer plotdannelsen, kunne etnograferne ikke være mere ligeglade.

Selv denne betragtning uagtet er den etnografiske teori fejlbehængt i sit inderste. Ifølge denne teori er fortællingers motiv-situationer erindringer om forhold, der har eksisteret i virkeligheden. (Shklovsk, 17-18)

Man kan fremføre mange logiske argumenter mod den etnografiske skoles referentielle motivforståelse, og Šklovskij er ikke sen til at harcelere over den naive fejlfortolkning af motiver som kulturhistorisk evidensmateriale. ${ }^{16}$ Præcis som symbolisterne - om end selvfølgelig på en helt anden måde - går etnograferne i referens-fælden. Dette betyder, til Šklovskijs store fortrydelse, at de negligerer væsentlige infralitterære spørgsmål, herunder ikke mindst det litteraturvidenskabelige kernespørgsmål om plotkonstruktion eller altså sammenkædningen af motiver til større narrative enheder (som Šklovskij senere i Prosateorien kommer til at beskæftige sig indgående med). ${ }^{17}$ Der er faktisk rigtigt meget at bygge på i den etnografiske skoles motivstudier, fornemmer man. Motivbegrebet må imidlertid, ifølge Prosateoriens tankesæt, nødvendigvis omdefineres til en formelagtig størrelse uden relation til nogen ekstralitterær virkelighed, altså til almensted eller topos.

16 Se Shklovsky (38): "Under Sturm und Drang i Tyskland var den overvældende størstedel af stykker skrevet inden for et tidsrum på fem år baseret på emnet brodermord. Således afbilder f.eks. samtlige tre stykker, der deltog i en konkurrence på et teater i Hamburg i 1776, netop sådan en forbrydelse Uulius von Tarent af Leisewitz, Klingers Tvillingerne og De ulyksalige brødre af en anonym forfatter). Schillers Røverne har også affinitet til temaet. Dette beviser dog ikke, at brodermord forekom i hobetal i datidens Tyskland."

17 Se kapitlerne om Don Quijote (den eksemplariske rammefortælling) og Tristram Shandy (plotløs fortælling). 
I sidste instans har Veselovskij, ligesom også Potebnja, således udstyret Šklovskij med en solid basis for hans egentligt topologiske poetik: en poetik, der tager udgangspunkt i det 'formelagtige' som centralt litterært greb.

\section{OPSAMLING}

For Šklovskij bliver topologien altså både en nøgle til forståelsen af selve 'det litterære' (som den demonstrative anvendelse af konventionelle billeder og motiver med henblik på fremmedgørelse), og en måde at anskueliggøre den litteraturhistoriske udvikling som en traditionsbruddets tradition eller proces af stadige fremmedgørelser af sådanne konventionelle former. I begge tilfælde er der tale om en deskriptiv infralitterær betragtningsmåde, der imidlertid har en relativ klar formuleret litteraturfilosofisk overbygning. Fremmedgørelsen er hos Šklovskij på ingen måde en ren provokatorisk eller destruktiv gestus, men sigter tværtimod mod at revitalisere eller genfortrylle den tristesse-ramte og automatiserede livsverden, så vi kan engagere os i den igen. Tilsvarende er det videnskabelige fokus på fremmedgørelsen ikke udtryk for en elfenbenstårnsagtig tilgang til litteraturen, men danner tværtimod udgangspunkt for en refleksion over litteraturens samfundsmæssige funktion.

Nærmere betragtet kan denne kobling mellem det videnskabelige og det filosofiske ses som en logisk konsekvens af Šklovskijs dybest set aristoteliske optik. ${ }^{18}$ For også Aristoteles anskuede jo tragediens forskellige formgreb - peripeteia og anagnorisis, for nu at nævne de mest udførligt beskrevne - som instrumenter, der muliggjorde dens overordnede samfundsmæssige funktion: katharsis. Paradigmet for Prosateoriens forening af poetologisk videnskab og litteraturfilosofi findes således helt klart i Poetikken, og den aristoteliske åre, der løber gennem dette på mange måder avant-gardistiske hovedværk, ${ }^{19}$ definerer det som meget mere end et tidsty-

"Aristotelisk" først og fremmest i forståelsen deskriptiv og analytisk, snarere end normativ og fortolkende. Jævnfør Aristoteles' Poetikken, der nøgternt beskriver generelle strukturer og mekanismer. For en uddybning af det i denne forstand aristoteliske ved Šklovskijs projekt, se Todorov 1973 (6-10).

19 Se tidligere omtalte kapitel i min Don Quijote og romangenren for en grundig beskrivelse af denne æstetik. 
pisk udtryk for det tidlige 20. århundredes æstetiske tænkning. Šklovskijs topologiske poetik kan vitterligt opfattes som et højdepunkt i den moderne aristotelisme, og i forlængelse heraf som en interessant samtalepartner for toposstudier af den curtiuske støbning, der ligeledes forener empiriske og syntetiserende betragtningsmåder, om end på en noget anderledes måde.

Curtius' "litteraturfænomenologi", som han selv benævner sin praksis (Curtius 10), står på den ene side solidt plantet i filologien som eksakt videnskab, men er på den anden side grundlæggende præget af en platonisk-transcendental videnskabsidealisme nedarvet fra den tidlige tyske romantik. Det er i denne sammenhæng essentielt, at Curtius netop så topologien som en måde at forene disse to traditioner. ${ }^{20}$ Hos ham fører topologiens forening af konkrete og abstrakte perspektiver imidlertid ikke til nogen eksplicit formuleret litteraturfilosofi, men derimod til etableringen af en litteraturhistorisk metodologi. Som det tydeligt fremgår af forordet til den tyske 2. udgave af Europäische Literatur und Lateinisches Mittelalter skal dialektikken mellem videnskabelig "universalisme" og "specialisering" (Curtius 10) forstås som en mediering af to historiske betragtningsmåder, abstraherende fugleperspektiv og et jordnært horisontalt perspektiv. I den forstand kan Curtius' topologi ses som en litteraturhistorisk metode, der er bundet op på en dobbelt forståelse af litteraturens formler dels som specifikke empiriske forekomster, dels som symptomer på en overordnet epokal ånd (Gelley 584).

Dette adskiller den fra Prosateoriens topologiske poetik, hvor undersøgelsen af det formelagtige i litteraturhistorien utvetydigt sker med henblik på at identificere en decideret transhistorisk "litteraritet": litteraturens dybere mening uafhængigt af tid og rum. Šklovskij lægger et ekstra spekulativt lag på, og dette sker på bekostning af den balance mellem universalisme og specialisering, som Curtius fremhævede som et ideal. Man kan sige, at vægtskålen i Prosateorien tipper helt og aldeles til den universalistiske

20 Se Gelley 586: "'A medieval scholarship which went no further than philology could never satisfy me, "he [Curtius] wrote, "Out of the detailed labor of philology there must be formed a historical viewpoint that will disclose new structures of the mind" (GA [Gesammelte Aufsätze zur romanischen Philologie, 1960], 118). It was through topology that Curtius sought a new synthetic method firmly grounded upon the data of philology." 
side, og at Šklovskij endda forstår universalisme i en langt mere radikal forstand end Curtius. Historisk specifikke detaljer træder fuldstændigt i baggrunden, og der springes frejdigt fra oldindiske eventyr til Cervantes og videre til Gogol. Det er emfatisk målet - afdækningen af litteraturens fremmedgørende essens som afsløret i dens formelagtighed eller altså i de litterære topoi - og ikke vejen, det drejer sig om her. Hvis topologien for Curtius er en litteraturhistorisk metode, er den for Šklovskij et litteraturfilosofisk redskab, kan man sige.

Sofie Kluge, dr. phil. og lektor i litteraturvidenskab, Institut for Kulturvidenskaber, SDU. Forfatter til bøger og forskningsartikler om, primært, den europæiske 1500 og 1600-talslitteratur og dennes reception. Aktuel med Honest Entertainment, Transcendental Jest. Six Essays on Don Quijote and Novelistic Theory (Kassel 2016).

TOPOLOGICAL POETICS IN VICTOR SHKLOVSKY'S THEORY OF PROSE

Though not explicitly addressed as such, the literary topos plays a crucial role in Russian literary theorist Victor Shklovsky's Theory of Prose (1925). On the backdrop of a critical discussion of the 'symbolist' conception of literature and of the 'ethnographical school's' exploration of literary motifs, Shklovsky here presents what can be understood as a genuine topological poetics: A poetics bent on the 'formulaic' as quintessential literary device. Rather than a figuration of the author's ideas literary images are, according to Shklovsky, conventional formulas that circulate in language. Rather than collective commemorations of original customs literary motifs exhibit literature's revitalization of 'automatized' language. Thus redefined as topoi in this most basic sense - as commonplaces or repetitions of existing forms literary images and motifs become key to understanding 'literariness' itself as a redeeming 'estrangement' of dead language forms and to conceptualizing literary history as a chain of successive estrangements. Qualifying the topos as self-referential, estranging device, Theory of Prose thus presents an original if also thought-provoking contribution to topology. However, it ultimately rest on a today questionable literary philosophical premise: The idea of literature as a privileged discursive space where the lost ideality of the life-world is recreated. 


\section{KEYWORDS}

EN: automatization; estrangement; literariness; conventionality; formalism; philosophy of literature; device; revitalization.

DK: automatisering; fremmedgørelse; litteraritet; konventionalitet; formalisme; litteraturfilosofi; greb; revitalisering.

\section{LITTERATUR}

Curtius, Ernst Robert. Europäische Literatur und Latinisches Mittelalter. Bern: Francke, 1954 (1948).

Eagleton, Terry. Literary Theory: An Introduction. Cambridge: Blackwell, 1996.

Ehrlich, Victor. Russian Formalism. History-Doctrine. The Hague/Paris: Mouton, 1969.

Gelley, Alexander. "Ernst Robert Curtius: Topology and Critical Method". MLN 81.5, 1966, 579-94.

Gumbrecht, Hans Ulrich. In 1926. Living on the Edge of Time. Cambridge MA: Harvard University Press, 1997.

Jameson, Fredric. The Prison-House of Language: A Critical Account of Structuralism and Russian Formalism. New Jersey: Princeton University Press, 1972.

Kluge, Sofie. Don Quixote og romangenren. København: Museum Tusculanums Forlag, 2006.

Ordbog over det danske sprog. Online udgave: http://ordnet.dk/ods. Set 12. november 2016. Readings in Russian Poetics, eds. L. Matejka \& K. Pomorska. Cambridge: MIT Press, 1971. Robinson, Douglas. Estrangement and the Somatics of Literature: Tolstoy, Shklovsky, Brecht. Baltimore: John Hopkins University Press, 2008.

Russian Formalism. A Retrospective Glance, eds. R. L. Jackson \& S. Rudy. New Haven: Yale UP, 1985.

Šklovskij, Viktor. Theorie der Prosa, übersetzt von Gisela Drohla. Frankfurt am Main, Fischer Verlag, 1984.

Shklovsky, Victor. Theory of Prose, translated by B. Sher with an Introduction by G. L. Bruns. Parkwood Elms: Dalkey Archive Press, 1990.

Steiner, Peter. Russian Formalism. A Metapoetics. Ithaca/London: Cornell University Press, 1984.

Striedter, Jurij., ed., Russischer Formalismus. Texte. München: W. Fink, 1988.

Théorie de la littérature. Textes des formalistes russes réunis, présentés et traduits par Tzvetan Todorov. Préface de Roman Jakobson. Paris: Éditions du Seuil, 1965.

Thompson, Ewa. Russian Formalism and Anglo-American New Criticism. The Hague: De Gruyter Mouton, 1971.

Todorov, Tzvetan. "Some Approaches to Russian Formalism". Russian Formalism. A Collection of Articles and Texts in Translation, eds. S. Bann \& J. E. Bowlt. Edinburgh: Scottish Academic Press, 1973, 6-10.

Todorov, Tzvetan. Literature and its Theorists: a Personal View of Twentieth-Century Criticism. London: Routledge \& Kegan Paul, 1987. 